\title{
Urban Foodscapes and Greenspace Design: Integrating Grazing Landscapes Within Multi-Use Urban Parks
}

\author{
Shannon Davis * \\ Centre of Excellence, Designing Future Productive Landscapes, Lincoln University, Lincoln, New Zealand
}

Since the early 2000s an increasing number of planning and design projects, within the spatial design fields of landscape architecture and urban design, have focused on food landscapes and their re-integration into the urban environment; particularly as a result of recent global movements toward creating more sustainable cities and human settlements. This article explores the potential contribution of grazing lands within cities of the Global North as a multi-beneficial layer in public greenspace design. Plant-based urban farms and community gardens have experienced significant growth

OPEN ACCESS

Edited by:

lain James Gordon Australian National University, Australia

Reviewed by: Monika Egerer,

Technical University of

Munich, Germany

Susan Parham

University of Hertfordshire,

United Kingdom

*Correspondence:

Shannon Davis

shannon.davis@lincoln.ac.nz

Specialty section:

This article was submitted to Agroecology and Ecosystem Services, a section of the journal

Frontiers in Sustainable Food Systems

Received: 04 May 2020 Accepted: 18 January 2021 Published: 25 March 2021

Citation:

Davis S (2021) Urban Foodscapes and Greenspace Design: Integrating Grazing Landscapes Within Multi-Use Urban Parks.

Front. Sustain. Food Syst. 5:559025. doi: 10.3389/fsufs.2021.559025 within developed nations in recent years, in both scholarship and practice, however the design and implementation of integrated grazing lands within the urban zone has been largely left out. For much of the Global North animal agriculture is still considered primarily rural. This research considers the potential of integrating grazing lands within the city through multiuse greenspace design, and undertakes a case study design critique of Cornwall Park, Auckland where since 1903, the Park has provided urban grazing for sheep and cattle, alongside other land uses and experiences such as recreation, heritage, bio-diversity, and education. Undertaking a "descriptive critique" of Cornwall Park, and its 100 Year Master Plan, this research is intended to enhance, the understanding and role, grazing animals can play within public greenspace.

Keywords: greenspace, public park, urban agriculture, animal agriculture, grazing lands, urban food system

\section{INTRODUCTION}

As a basic essential for life, food has always been a critical part of any city including its production, movement and transportation, distribution, places of consumption, and waste (Pothukuchi and Kaufman, 1999, 2000; Steel, 2008, 2012, 2020; Viljoen and Bohn, 2014; Parham, 2015). The spatial relationship between food production and urban settlements has been critical in the development of cities and civilizations throughout the world, and the design and provision for spaces that allowed farming and agricultural practices to occur have been part of cities since they first developed over 10,000 years ago. Being considered an essential infrastructure, urban, and peri-urban based agriculture was integral to the success of cities globally throughout history (Pothukuchi and Kaufman, 1999, 2000; Viljoen, 2005; Steel, 2012, 2020; Morgan, 2014; Viljoen and Bohn, 2014; Parham, 2015; Kasper et al., 2017). With the advent of railways, however, in the nineteenth century, many cities of the Global North were essentially liberated from the spatial constraints of the traditional geography of such things as food production and walkability, making it possible to 
build and extend urban settlements that were less constrained by size, shape, and location (Steel, 2012). With many cities in the Global North today relying on long and complex food supply chains, understanding around the localization of food production and access within urban settlements has grown in recent years (Pothukuchi and Kaufman, 1999; Morgan and Sonnino, 2010; Opitz et al., 2016). This paper looks to expand the existing scope of urban agricultural research, usually focused on plantbased production, focusing instead on the design of grazing land for animal husbandry and meat production within urban greenspaces. Using a case study methodology, that includes site and document analysis, this research explores, using a depictive criticism approach, the design of Cornwall Park, and its "100 Year Master Plan" design document, analyzing how a working beef and sheep farm can be successfully integrated within a city context. Cornwall Park provides an example of the multifunctional dimensions of integrating agriculture, in particular grazing lands for livestock, in a multi-use public park alongside other land uses and experiences such as ecology, aesthetics, heritage, recreation, bio-diversity, and education.

With current concerns around climate change, environmental quality, and the health and well-being of urban residents at the forefront of city planning, the practice and development of urban food landscapes is recognized as essential to the longterm sustainability of urban settlements globally (Pothukuchi and Kaufman, 1999; Viljoen, 2005; Morgan and Sonnino, 2010; Duany and DPZ, 2011; Morgan, 2014; Opitz et al., 2016). Discussed by Duany and Talen (2002), the "urban zone" consist of four zones along the rural-urban continuum, namely the "sub-urban," "general urban," "urban center," and "urban core" zones, characterized by levels of increasing residential and built infrastructure density, increasing levels of mixed use development (including residential, retail, offices, entertainment, cultural, and public open space), and increasing maximum building heights (Duany and Talen, 2002). When considering the rural-urban transect, these urban zones are in addition to two rural zones-namely "rural preserve" and "rural reserve" (Duany and Talen, 2002, p. 255). In response to the growing environmental, climate and urban well-being concerns, various food movements have advocated strategies for re-spatializing food systems, including reducing food miles with shortened supply chains, and embedding farming in local urban ecologies (Feagan, 2007). Since the early 2000s, "urban agriculture," defined by Mougeot (2006) as "the growing, processing, and distribution of food and non-food plant and tree crops and the raising of livestock, directly for the urban market, both within and on the fringe of an urban area" (Mougeot, 2006, p. 4), has significantly transformed the fundamental notion of the city once again, by inverting the urban/rural dichotomy of the Global North by re-inserting food production back into parks, vacant lots, and rooftops within the urban zone. Urban animal agriculture, however, has not been widely included in the contemporary rise and interest in urban agriculture seen recently within developed nations. Today however, with increased interest in urban resiliency and sustainable food systems, spatial planners, and designers are seeking to re-accommodate animal agriculture into urban settings within the Global North, alongside the more common plant-based practices. Although cattle and other grazing stock have been used in regional parks and public rangelands both in New Zealand and internationally, the inclusion and integration of grazing stock in public urban parks has not been widely implemented, with policies around animal husbandry within urban limits of the Global North proving a significant barrier to providing space and facilities for grazing animals within cities.

Public greenspaces in cities play a critical role within the urban environment, and throughout history have fulfilled many functions from providing space for decorative public gardens and the curating of botanical species during the eighteenth century, to providing fresh air for invalids and tuberculosis sufferers in the nineteenth century, and for the communal production of food during the twentieth century World War's (van Leeuwen et al., 2010, pp. 20-21). The public park is one of the most recognizable typologies within the urban environment and is an indispensable element of urban quality, providing amenity and services to both urban residents and environmental systems. As Parham and Abelman (2018) discuss, urban parks provide an example of an urban typology with food space potential (p. 412). The various functions of urban greenspaces show that they have a complex and multidimensional structure, containing important ecological, social, and economic values that contribute to the overall sustainability and quality of life for urban dwellers (van Leeuwen et al., 2010, p. 21). Recently focusing on functioning as places for passive and active recreation, urban greenspaces are seen as multi-use providing spaces not only for recreation, leisure, rest, and relaxation, but also places for urban biodiversity, wildlife habitat, stormwater management, urban cooling, and increasingly, urban food production (Morgan, 2014).

Since the early 2000s, the practice and implementation of urban agriculture within publicly-owned greenspaces has grown in both location and scale, moving from a peripheral position within local government and urban design disciplines to one that is seen as a viable and progressive way forward for cities of the Global North to meet urban resilience agendas, increasing residents access to fresh nutritious food, and supporting human relationships with the land (Viljoen and Bohn, 2005; Mougeot, 2006; Morgan and Sonnino, 2010; Morgan, 2014; Parham, 2020). As discussed at length by authors such as Morgan and Sonnino (2010), Morgan (2014), Parham and Abelman (2018), Viljoen (2005), Viljoen and Bohn (2005, 2014), Viljoen et al. (2015), and Pothukuchi and Kaufman (1999, 2000), urban agriculture makes a positive contribution to food security, food safety and energy savings by shortening the chains that distribute food. "Immediate advantages such as freshness of fruit and vegetable, better choice of high quality meat products and simple processes for food traceability all mark a new trend in urban consumption and behavior" (van Leeuwen et al., 2010, pp. 21-22). Including a diverse range of activities from the cultivation of fruit and vegetables, medicinal plants, spices, and mushrooms, as well as the production of eggs, milk, meat, and wool, urban agriculture within public parks can also contribute to a reduction in maintenance cost (with the use of grazing animals, or the inclusion of food forests for example), and diversification of income streams (Mougeot, 2006; Morgan, 2014). The integration of urban agriculture into densely populated areas also greatly 
extends the opportunities for combining food production with the ecological and social functions of urban greenspaces. Offering an alternative land use for integrating multiple functions within city limits, urban agriculture can contribute a high degree of multifunctionality to urban environments (Viljoen and Bohn, 2005, 2014; Morgan, 2014; Viljoen et al., 2015; Parham and Abelman, 2018). In addition to the production of food, urban agriculture offers a wide range of associated benefits including ecological functions such as biodiversity and nutrient cycling; and cultural functions, for example, physical exercise, education for life skills, and social interaction and inclusion.

Design professions such as landscape architecture and urban design can play a critical structural role in developing "healthier" cities, responding to, as Potteiger (2013) discusses, public health problems and their solutions. He suggests, in the nineteenth century pathogens were identified as the primary cause of death in many European cities and thus became the central focus of public health. Contaminated wells were recognized as sources for the spread of contagious disease, and this realization led to the design of city water and sanitation infrastructure throughout the world, stating, "since the mid-20th century, the public health paradigm has shifted from a singular focus on infectious disease to a focus on chronic illness-heart disease, cancer, diabetes, and high-blood pressure-diseases in which diet as well as environment and behavior play a critical role" (Potteiger, 2013, p. 264). It follows therefore, that urban planning and design can play an important role in solving current public health problems through the design of cities that promote healthier lifestyle, a sense of community, and better nutritional options (Morgan, 2014). The integration of food landscapes within urban form therefore, could aid in many of the contemporary health issues, both mental and physical, being faced by our urbanizing, aging population. Offering multiple benefits to surrounding residents, the integration of agriculture into urban environments improves access to fresh and nutritious food, and in doing so can play an important role in combating obesity, diabetes, and poor nutrition, as well as supporting mental health and well-being (Potteiger, 2013, 2015). Residents can participate in urban agriculture through, for example, involvement in community gardening, school gardens, urban orchards, food forests, or farmers markets. Urban agriculture can also provide a community with access to rare foods that support their cultural customs, or heritage varieties not sold by the larger exportorientated producers.

The inclusion of animal husbandry as part of urban agriculture practice, although being an integral part of urban living in the past, has been actively planned out of many cities within the Global North over the last 100 years. Animal agriculture once provided many cities of the Global North with waste management and transportation, in addition to an important food supply. The spatial relationship between rural and urban was a continuum where food production was a visible and vital component of urban systems as well as rural (Brinkley and Vitiello, 2014). However, as cities became more crowded, enabling the easier spread of disease, alongside the invention of the railroad, agricultural production, especially animal agriculture, was zoned out of many settlements within the Global North.
New Zealand, a nation well-known for its primary production and agricultural culture consists of 26.8 million hectares, inclusive of off-shore islands. Of this, agriculture covers $53.4 \%$ (13.8 million hectares), exotic forestry $8.1 \%$ (2.1 million hectares), native forest $29.6 \%$ (7.6 million hectares), and "other" land (e.g., mountains, urban) 11.2\% (3.0 million hectares) (Journeaux et al., 2017, p. 9). In New Zealand, animal agriculture is still today overwhelmingly considered to be a rural land use activity with vast areas of rural land supporting large-scale primary production. Animal-based agriculture is not a common practice within the urban zones in New Zealand, instead primarily operating within the rural landscape. Cornwall Park in Auckland however (New Zealand's largest city with a 2017 population of 1.66 million-35\% of New Zealand's total population) provides an important case study example of an urban park facilitating multiple land uses including grazing land and animals. Using Cornwall Park as a case study, this research poses the question, how can grazing lands, for sheep and beef production, be designed within a public urban park alongside other park uses?

\section{METHODS}

A qualitative case study methodology was selected to deepen understanding of Cornwall Park, specifically the role grazing lands and animals play within it. The first step in a larger research project investigating the enablers and barriers to reintegrating animal-based agriculture within urban greenspaces of the Global North, the research presented in this paper uses a descriptive critique method to investigate the Master Plan document produced in 2014 (Boffa Miskell and Nelson Byrd Woltz Landscape Architects) to oversee the future development of the Park. Using Attoe's (1978) sub-category of "depictive criticism," within the "descriptive criticism" classification, this research sets out to enhance the understanding of grazing lands as an integrated land use within Cornwall Park. Bowring explains, "Descriptive criticism is a category which includes writing about the designed work in factual ways, in contrast to the creativity of interpretive criticism. It is not an evaluative approach, but one which is intended to enhance the understanding of the work within its context" (Bowring, 2020, pp. 31-32). Sitting within the classification of "descriptive criticism," "depictive criticism" aims to elucidate static or dynamic aspects of a building or landscape. "It will be argued that depictive criticism is not criticism at all since no stand on the question of 'good' or 'bad' is taken. Buildings [or landscapes] are simply depicted" (Attoe, 1978, p. 85). This form of criticism performs an important service by forcing attention on special aspects of the landscape and telling us to "see" them, setting up the possibility of a new experience directed by this factual approach to design criticism. Further survey-based research looking at the perceptions and attitudes of surrounding residents to the inclusion of animal agriculture within the Park is proceeding as part of the larger study, and this will be followed by interviews with residents, park users, and park management. In this first stage of research, forming a deep understanding of 
the site and context is key to successfully translating survey and interview data into meaningful analysis and interpretation.

Case studies are a structured way of recording design projects, and according to Francis (2001), the use of case study methodology has a long and well-established history in landscape architecture and other design disciplines, typically used to describe and/or evaluate a project or process (p. 15).

The implementation of spatial, infrastructural, and land use changes proposed by the expert-driven Cornwall Park 100 Year Master Plan, are in the early stages and, therefore, the descriptive critique of the case study outlined below focuses on the initial case study steps of investigating the spatial, historical and contemporary context; the project background and vision set by the Cornwall Park Trust Board Inc. (in conjunction with landscape architecture firms Boffa Miskell and Nelson Byrd Woltz Landscape Architects); and site analysis carried out through both site visits and the exploration of the detailed Master Plan document.

\section{CASE STUDY}

New Zealand is known worldwide for its primary food and fiber production. Agriculture is vital to the economy as well as being important in terms of national heritage and identity. Today however, the urban population exceeds $80 \%$ of New Zealand's total population, with many New Zealanders having little or no physical or social connection to productive landscapes. Providing opportunities to experience land and agricultural processes within cities is deemed increasingly important as New Zealand's population urbanizes and the spatial divide between rural and urban grows.

Tāmaki-makau-rau Auckland is New Zealand's largest city, with much of the urban extent built on lava and volcanic debris from the 48 volcanoes that comprise the Auckland landscape, within a $20 \mathrm{~km}$ radius. Maungakiekie One Tree Hill is one of Auckland's most iconic volcanic features [Figure 1 illustrates the memorial obelisk at the summit of Maungakiekie One Tree Hill, with landscape terracing created during Māori occupation of this former $\mathrm{Pa}$ (village and fortification) site]. Having erupted 20,000-30,000 years ago, the event created a complex scoria cone with extensive lava flows. Three craters were formed during the eruptions. These three craters today form the Maungakiekie One tree Hill Domain, which borders Cornwall Park. As the city of Auckland has grown in both population and spatial extent, since 1903 Cornwall Park has provided a multi-use public greenspace where animal grazing has played, and continues to play, an important role in the maintenance, educational and heritage value of the central city landscape (Panel shows an aerial image of Tāmaki-makau-rau, Auckland, indicating the location of Cornwall Park and Maungakiekie One Tree Hill Domain within the city of Auckland Google, 2020). A site rich in Māori cultural heritage and settler agricultural history, the Park was gifted to the people of New Zealand by Sir John Logan Campbell, and now sits centrally in New Zealand's biggest city.

The land which today constitutes Maungakiekie One Tree Hill, which borders Cornwall Park, holds significant national cultural value within New Zealand-being one of the most extensive former Pa sites in New Zealand. During pre-settlement times Māori occupation of the land saw the creation of extensive terraces built primarily to house sites for food storage pits and hearths. Kumara (sweet potato) was stored for winter in pits to preserve the tubers in an even temperature and humidity. Vast areas of cultivated land around Maungakiekie supported the inhabitants with crops of kumara, yam, and taro, grown in the fertile volcanic soils that are now part of Cornwall Park (The Cornwall Park Trust Board Inc, 1994). Māori population peaked in this area during the sixteenth and seventeenth centuries, but with increasing inter-tribal warfare, saw, by the 1820 's, survivors relocate to surrounding regions and districts. This was the situation as European settlers arrived in the 1840's to find no people living on Maungakiekie (The Cornwall Park Trust Board Inc, 1994). In 1853 John Logan Campbell and William Brown
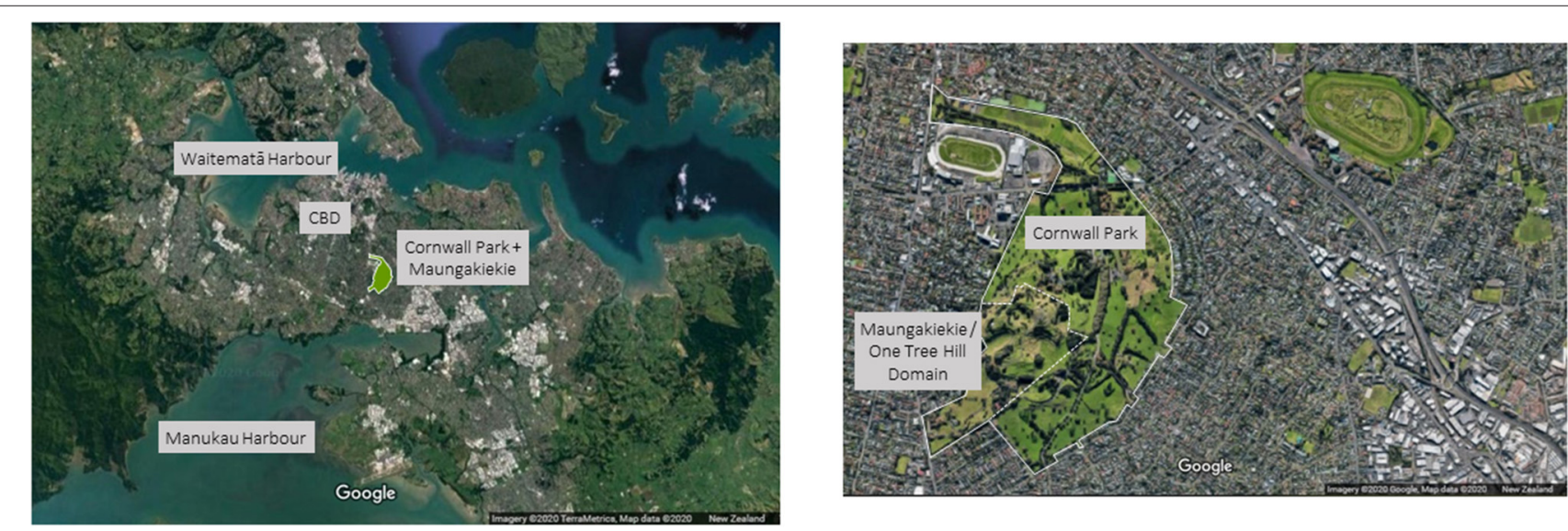

FIGURE 1 | Aerial images of Cornwall Park and Maungakiekie One Tree Hill Domain showing urban context and density. Map 1: Adapted from Google Earth, Imagery (C2020 TerraMetrics, Map data ๑2020 New Zealand. Map 2: Adapted from Google Earth, Imagery @2020 Google. Map data @2020 New Zealand (Google, 2020 ). 
bought the One Tree Hill Estate from Irish settler Thomas Henry. In 1871, the partnership with Brown was dissolved and Campbell took over the farmland adjacent to Maungakiekie One Tree Hill Domain (Maungakiekie One Tree Hill had been taken as public reserves by a commission court set up by Governor Gray). In 1901 Campbell bequeathed the One Tree Hill estate to the people of Auckland, naming the estate Cornwall Park. Between 1901 and 1903, Campbell's main aim was to the convert the farm into a public park. He employed 20-year-old Landscape Architect, Austin Strong to conceptualize his vision. The founding principle of Cornwall Park, preserved in the Deed of Trust, dedicated the Park as a place of recreation in service to the people of New Zealand (The Cornwall Park Trust Board Inc, 1994).

For 120 years Cornwall Park has sat surrounded by a changing landscape-from farmland to suburban neighborhoods, to today sitting within a medium - high density residential urban zone. "The land surrounding Cornwall Park has seen dramatic change, from open farmland to a popular residential neighborhood. With his gift of the lands for Cornwall Park, Sir John Logan Campbell envisioned this growth, dedicating the park as a space for recreation that he knew would be in higher demand as the city grew" (Boffa Miskell and Nelson Byrd Woltz Landscape Architects). Cornwall Park encompasses 172 ha of public greenspace (Figure 1 indicates an aerial image of Cornwall Park and Maungakiekie One Tree Hill Domain showing urban context and density). It is located in the Auckland suburb of Epsom, and using the work of Andre Duany, sits within the "General Urban" zone (Duany and Talen, 2002, p. 255) surrounded on all sides by predominantly medium to high density residential land, i.e., 30-50 people per hectare (Fredrickson, 2014, p. 33). In 2014, Boffa Miskell (NZ) and Nelson Byrd Woltz Landscape Architects (USA) were engaged by the Cornwall Park Trust Board to produce a 100 Year Master Plan for the Park, that would ensure its long-term future as an important urban greenspace for Auckland city (refer Table 1 for baseline information and context, and Table $\mathbf{2}$ for a summary of the site design details).

The Master Plan outlines six guiding principles (refer Table 3) that represent the underlying values of the Cornwall Park development. Each principle is applied to the site through multifunctional approaches to landscape management, environmental stewardship, user experience, and a commitment to continue and develop the agricultural heritage legacies of this landscape. These principles, discussed and analyzed below, explore the concept of reintegrating grazing lands for sheep and beef production within a public urban park alongside other park uses, with the masterplan design (as illustrated in Figure 2) illustrating the spatial implementation and development of these principles.

The guiding principle of Kaitiakitanga recognizes the important role Cornwall Park plays as a regional resource, with regards to both its size, shape, and location within the wider Auckland landscape. "As Auckland grows, the habitats within the park will become even more valuable to native flora and fauna both locally and regionally. Increasing the biodiversity within the park will enhance the overall ecological value as well as the park's resiliency to potential challenges such as disease, storms and climate change" (Boffa Miskell and Nelson Byrd Woltz
TABLE 1 | Baseline information/context.

\begin{tabular}{|c|c|c|}
\hline Location & \multicolumn{2}{|l|}{ Epsom, Auckland } \\
\hline Size & \multicolumn{2}{|c|}{$\begin{array}{l}172 \text { ha (wrapping around Maungakiekie One Tree } \\
\text { Hill and One Tree Hill Domain) }\end{array}$} \\
\hline Client & \multicolumn{2}{|c|}{ The Cornwall Part Trust Board } \\
\hline Designer & \multicolumn{2}{|c|}{ Landscape Architect Austin Strong } \\
\hline Ownership & \multicolumn{2}{|c|}{$\begin{array}{l}\text { Cornwall Park-Cornwall Park Trust } \\
\text { One Tree Hill Domain-Tupuna Maunga o Tāmaki } \\
\text { Makaurau Authority (Maunga Authority) and } \\
\text { Auckland Council }\end{array}$} \\
\hline Date & \multicolumn{2}{|l|}{1903} \\
\hline Land use type & \multicolumn{2}{|c|}{ Urban Greenspace-Public Park } \\
\hline $\begin{array}{l}\text { Landscape } \\
\text { features }\end{array}$ & \multicolumn{2}{|c|}{$\begin{array}{l}\text { Maungakeike One Tree Hill } \\
\text { Highly valued cultural landscapes of national } \\
\text { importance } \\
\text { Significant archeological sites }\end{array}$} \\
\hline Park features & \multicolumn{2}{|c|}{$\begin{array}{l}\text { Parkland, extensive historic tree plantings (exotic, } \\
\text { native and fruit), agricultural land, historic agricultural } \\
\text { infrastructure (stone walls), café, restaurant, } \\
\text { discovery hub, historic cottage, memorial, rongo } \\
\text { stone, playground, band rotunda, folly }\end{array}$} \\
\hline $\begin{array}{l}\text { Underlying } \\
\text { challenges of the } \\
\text { site }\end{array}$ & \multicolumn{2}{|c|}{$\begin{array}{l}\text { Nationally significant pre-settlement archeological } \\
\text { sites } \\
\text { Important geological land formations - volcanic } \\
\text { boulder fields } \\
\text { Surrounded on all sides by medium-density } \\
\text { neighborhoods } \\
\text { Four-lane Green Lane cuts the northern precinct off } \\
\text { from the rest of the Park }\end{array}$} \\
\hline $\begin{array}{l}\text { Current } \\
\text { Management }\end{array}$ & $\begin{array}{l}\text { Cornwall Park Trust } \\
\text { Board } \\
\text { Park Director } \\
\text { Finance and } \\
\text { Administration } \\
\text { Manager } \\
\text { Property Manager (+ } \\
\text { Assistant) } \\
\text { Park Supervisor } \\
\text { Information Center } \\
\text { Manager } \\
\text { (+ 2xAssistants) }\end{array}$ & $\begin{array}{l}\text { Farm Manager } \\
\text { Horticulture Supervisor } \\
\text { Arborist } \times 2 \\
\text { Parks and Recreation } \\
\text { Manager } \\
\text { Principle Parks and } \\
\text { Recreation Specialist }\end{array}$ \\
\hline Users & $\begin{array}{l}\text { Neighbors } \\
\text { Auckland residents } \\
\text { Sports clubs } \\
\text { School groups } \\
\text { Walkers }\end{array}$ & $\begin{array}{l}\text { Fitness } \\
\text { Dog walkers } \\
\text { Mothers with babies } \\
\text { and young children } \\
\text { Educational groups } \\
\text { Event goers }\end{array}$ \\
\hline
\end{tabular}

Landscape Architects, p. 14). A focus on maintaining the Park's open landscape character, alongside improving visitor experience will see ecological resources made visible and legible to visitors, providing opportunities for visitors to connect with and care for the natural ecosystems present within the Park. Together with neighboring Maungakiekie One Tree Hill Domain, the urban greenspace forms the largest parkland in Auckland city, and the Master Plan proposes to offer visitors the opportunity to engage with the Park's ecology, and improve ecological value within the wider regional network, particularly for avifauna, and to "increase the Park's biodiversity, structural diversity and habitat 
TABLE 2 | Site design information.

\begin{tabular}{|c|c|c|}
\hline & $\begin{array}{l}\text { Original Park Design (The Cornwall Park Trust Board } \\
\text { Inc, 1994) }\end{array}$ & $\begin{array}{l}100 \text { Year Masterplan (Boffa Miskell and Nelson Byrd Woltz Landscape } \\
\text { Architects, 2014) }\end{array}$ \\
\hline Year & 1903 & 2014-ongoing \\
\hline Designer & Austin Strong, Landscape Architect & $\begin{array}{l}\text { Boffa Miskell (New Zealand) and Nelson Byrd Woltz Landscape } \\
\text { Architects (USA) }\end{array}$ \\
\hline Vision & $\begin{array}{l}\text { A public park for the rapidly growing city. A place } \\
\text { where people would be able to escape "the hustle } \\
\text { and bustle of the workaday world" }\end{array}$ & $\begin{array}{l}\text { A Park that remains the treasure of Auckland committed to providing } \\
\text { public places for recreation, exercise, learning, cultural expression, } \\
\text { connection to the land and to nature, and strengthening the bonds } \\
\text { of community. A Park that protects its sacred ground, celebrates } \\
\text { heritage, and expresses New Zealand's agricultural roots }\end{array}$ \\
\hline Goals & $\begin{array}{l}\text { To turn Cornwall Park from a farm into a park. } \\
\text { The design was intended to safeguard the } \\
\text { "magnificence and beauty" of the parks "natural } \\
\text { situation" while also providing for a large number of } \\
\text { leisure activities. }\end{array}$ & $\begin{array}{l}\text { Improve the park's ecological stewardship and resiliency } \\
\text { Reinforce and strengthen the park's design and aesthetic. Aspire to } \\
\text { beauty in all things } \\
\text { Support preservation and active interpretation of the park's cultural } \\
\text { heritage and history } \\
\text { Commit to agriculture as an important cultural legacy integral to } \\
\text { park management } \\
\text { Prepare the park to continue to serve the citizens of Auckland in a } \\
\text { dynamic future } \\
\text { Equip the park to transform from a suburban park to an urban park }\end{array}$ \\
\hline $\begin{array}{l}\text { Landscape } \\
\text { layers/landscape } \\
\text { features }\end{array}$ & $\begin{array}{l}\text { Carriage roads } \\
\text { Grand avenue and path to the summit (of } \\
\text { Maungakiekie One Tree Hill) } \\
\text { Sport } \\
\text { Agriculture } \\
\text { Structural tree planting } \\
\text { Shrubs and tree planting (combinations of both } \\
\text { native and exotic) }\end{array}$ & $\begin{array}{l}\text { Agricultural precinct } \\
\text { Sport Precinct } \\
\text { Core Precinct } \\
\text { Onehunga Precinct } \\
\text { (see further details below) }\end{array}$ \\
\hline Cost of Implementation & $\$ 2,000$ & Unspecified \\
\hline Awards & & $\begin{array}{l}2015 \text { ASLA Professional Award (Honor Award, and Analysis + } \\
\text { Planning) } \\
2017 \text { NZILA Category Winner-Strategic Landscape Planning and } \\
\text { Environmental Studies }\end{array}$ \\
\hline
\end{tabular}

TABLE 3 | Guiding Principles, Cornwall Park 100 year Masterplan (Boffa Miskell and Nelson Byrd Woltz Landscape Architects, 2014, pp. 14-15).

Kaitiakitanga

Tikanga

Nga mahi ahuwhenua

Turangawaewae

Manaakitanga
Stewardship as guardians of the deep links between humans and the natural world. embody and underpin the development of the park.

Support, protect, save, and uplift, as stewards of the park's unique history

The development of exemplary agricultural practices to provide sustenance and nourishment for people and visitors to the park.

A place to stand. The park as a place for Aucklanders to stand and have a sense of belonging.

Provide enduring support, hospitality, kindness, and vision for the park.
The principles and practices which

value with a system-wide approach that addresses planting, soil health, native food resources, and habitat connectivity" (Boffa Miskell and Nelson Byrd Woltz Landscape Architects, 2014).

Care is also provided in the Master Plan for the underlying Onehunga aquifer.

Tikanga, the second principle, responds to the unique character and beauty of the park. "All aspects of the park affect the perception of beauty and place-the combination of design, maintenance, history, natural features and the amination of its landscape by people" (Boffa Miskell and Nelson Byrd Woltz Landscape Architects, p. 14). The Master Plan proposes that strengthening the Park's aesthetic value should be inherent in every change and adaptation.

As has been a core land use in the past, the Master Plan continues to support and grow the agricultural legacy of the Park into the future. The cultivation of food has been part of the landscape, which is now known as Cornwall Park, for as long as humans, both Māori and European (refer Figure 3 showing grazing cattle and sheep within Cornwall Park) have inhabited that landscape. The principle of Nga mahi ahuwhenua celebrates the agricultural legacy of this place (Boffa Miskell and Nelson Byrd Woltz Landscape Architects, p. 14). Visitors experience the Park and all its uses alongside the animals (Figure 3 showing pedestrians using the park to commute between suburbs and avoid the busy roads by creating desire-line tracks through sheep and cattle paddocks). 


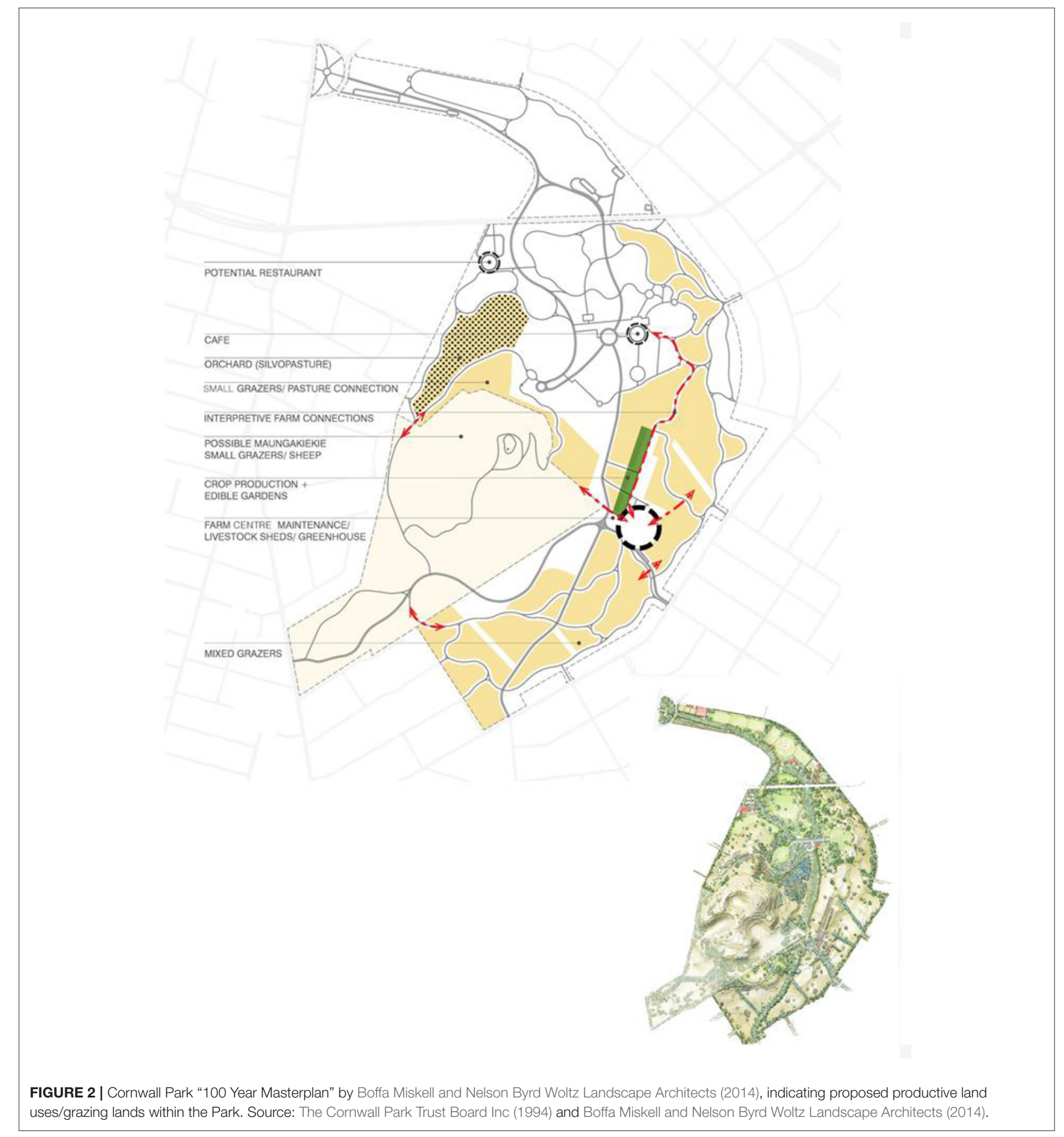

Tiaki Onamata recognizes the land as a precious resource, where the geology, soils, plant, and animal life is embodied in the landscape, and where the ground is understood as a precious resource (Boffa Miskell and Nelson Byrd Woltz Landscape Architects, p. 15).

The principle of Turangawaewae is a founding principle of Cornwall Park and is a value preserved in the Deed of Trust dedicating the Park as a place of recreation in service to the people of New Zealand, and is at the core of the Master Plan vision (Boffa Miskell and Nelson Byrd Woltz Landscape Architects, p. 15). As the population around the Park changes, the Park shall adapt allowing for the changing needs of the people it serves. "With the city and surrounding neighborhood continuing to urbanize, the next 100 years calls for a transformation of 

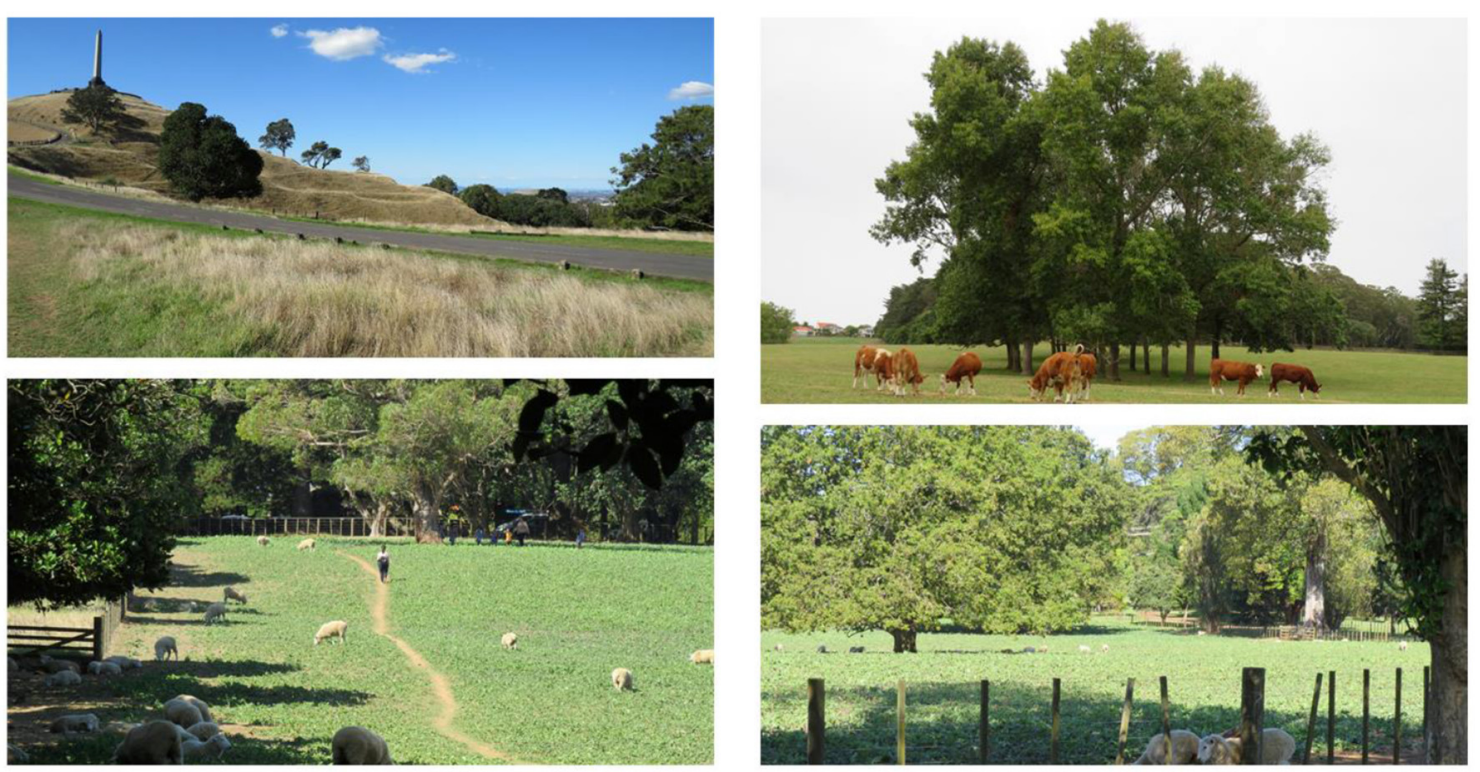

FIGURE 3 | Cornwall Park images, clockwise from top left: Obelisk at the summit of Maungakiekie One Tree Hill, with landscape terracing created during Māori occupation of this former Pā site; Grazing cattle within Cornwall Park surrounded by residential living; Sheep within Cornwall Park finding shade under large specimen trees; Pedestrians use the park to commute between suburbs and avoid the busy roads by creating desire-line tracks through sheep and cattle paddocks. Source: Photos by Shannon Davis.

parking space to park space and forging new public transportation connections privileging the pedestrian experience and increasing the amenity of the park" (Boffa Miskell and Nelson Byrd Woltz Landscape Architects, p. 15). The final principle of Maanakitanga responds to the need to change, support and provide an enduring vision of the Park.

Park layers outline and describe the multibeneficial aspects of the Park that sit within the same physical space and offer multiple functions, for example expressing landscape and cultural character, visitor experience and engagement, and function, whether that be ecological, recreation, leisure or agricultural. The layers described in the Master Plan include cultural landscapes, agriculture, park ecology, user experience, and infrastructure-activities situated in the same horizontal space, synthesizing, and working in combination to create multiple benefits across the landscape. People are invited to move through the landscape of the Park, choosing their own paths, and engaging with multiple land uses. It is only during springtime (September-November in New Zealand), when calving and lambing occurs, that visitors to the Park have limited access to some paddocks to ensure animal welfare, and human safety.

The quality of user experience is emphasized throughout the Master Plan with reference to Park aesthetics, connectivity and pedestrian orientation, upgraded Park facilities, as well as visitor education and community outreach programs. Due to the significant cultural value of Cornwall Park (and bordering Maungakiekie One Tree Hill), the Cornwall Park Master Plan proposes minimizing disturbance to the grounds of the Park, and also emphasizes the importance of preserving, protecting and adapting the historic landscape features for the long-term.
It integrates "Cultural Walks" with interpretation information of the Parks rich cultural history, both pre- and post-settlement. Legacy planting is prioritized by maintaining existing historic plantings and outlines a plan for their replacement over time. The establishment of "guidelines for farming in historic landscapes with sensitive geologic and archeological features" (Boffa Miskell and Nelson Byrd Woltz Landscape Architects, 2014) is also proposed.

The celebration of the rich agricultural heritage of the Park is integrated by the Master Plan through the proposed farm-totable production model, incorporating the existing livestock, with the introduction of pre- and post-European food crops, and then demonstrating the complete food story through featuring the products in the Parks cafés and proposed farmers market, and in the future, possibly a Park Farm store. Expanding the educational programs to "include interpretation of crops, historic gardens and contemporary sustainable gardening techniques... sits alongside new pasture layout to accommodate changes in grazing regimes" (Boffa Miskell and Nelson Byrd Woltz Landscape Architects, 2014).

The long term vision of the Master Plan sees Cornwall Park demonstrating a whole systems approach to agriculture, with production methods addressing global environmental issues and concerns (Boffa Miskell and Nelson Byrd Woltz). The Master Plan provides direction for a focus on increasing biodiversity, improving carbon sequestration, reducing use of inputs including oil and phosphates, providing innovative education and outreach, and long-term economic viability of the Park operating as a working farm (Boffa Miskell and Nelson Byrd Woltz Landscape Architects, 2014). The proposed introduction of gardens and crop production adds a new focus to the existing 
agriculture system, particularly with regard to the education of urban consumers-the Parks neighbors.

In an era where urban dwellers are increasingly isolated from the production of their food, Cornwall Park can serve as an important educator by implementing a sustainable farm-to-table model. This suggests a greater diversity of agricultural products, and celebration of the land's rich gardening history (Boffa Miskell and Nelson Byrd Woltz Landscape Architects, 2014).

The Master Plan proposes five design goals for the Agricultural Layer: (1) exemplify best practices for sustainable farming in heritage landscapes; (2) express Cornwall Park's cultural heritage and historic agricultural endeavors through contemporary examples of agricultural production; (3) practice a sustainable, holistic approach to livestock management and plant based food production, creating an exemplary farm-to-table working farm; (4) expand educational opportunities for visitors to connect with the agricultural heritage of New Zealand; and, (5) conserve and preserve novel ecologies while supporting and nurturing native ecosystems and associations.

Cornwall park is a place where New Zealanders can learn about their agricultural heritage. The current incarnation of livestock farming is a unique and beloved attraction that is essential to the maintenance of the park grounds. With the story of sustainable and local food production increasingly hidden from urban life, the introduction of crops and gardens can reflect the historic gardening the landscape has supported while engaging contemporary issues of local and sustainable farming (Boffa Miskell and Nelson Byrd Woltz Landscape Architects, 2014, p. 14)

The Masterplan proposes that the parkland driven, by agricultural systems, will comprise of $\sim 50$ ha of pasture within Cornwall Park itself. Current agricultural infrastructure will be retained such as pastures, shelterbelts, specimen tree planting, stockyards and existing farm buildings, and heritage production-based elements will be preserved and enhanced, such as remaining kumara storage pits, Māori garden remnants, and the Parks original stone farm walls.

Production types will continue a cattle stud herd, lamb and wool/pelts production, and the creation of a new agricultural hub within the Park where it is proposed heritage crops and orchards will be created alongside farm-to-table vegetable beds. Diversifying production management systems and models is prioritized for the Park building greater long-term resiliency. These production systems include Management Intensive Grazing (MIG) for pastures (both cattle and sheep), where the basic principle is to utilize pasture grasses at maximum efficiency by mimicking the grazing pattern of ruminants in the wild. "These animals move in herds at high density, grazing land thoroughly, and move regularly to new pasture. This pattern is replicated with rotations of domesticated herds using portable fencing and watering systems, closely monitoring pasture regrowth while maintaining appropriate stocking densities" (Boffa Miskell and Nelson Byrd Woltz Landscape Architects, 2014). Silvopasturing is the incorporation of trees into pasture lands and will be used to provide multiple benefits to both animals and land, while adding to the diversity and economic resiliency of the Park. Agroforesty will be adopted and "guilds" of plant communities will be selectively developed into Park landscapes. Areas of coppicing for timber and fuel will also be developed. Several plant-animal systems will be incorporated including areas where stock and vegetable fields operate for the benefit of both, where crops such as mustards and cabbages can be grown and once harvested, residues can be grazed offering winter feed for cattle (Boffa Miskell and Nelson Byrd Woltz Landscape Architects, 2014).

It is hoped that benefits derived from the diversifying of production systems within the Park, as outlined above, will result in carbon neutral livestock farming where animals are raised on grass-based diets, and are continuously rotated increasing the capacity of the land to store carbon through building soil organic matter. Fuel reductions will be achieved through reducing or eliminating winter feed production and grazing yearround will produce more biomass and soil biological activity. The establishment of seasonal based pastures with appropriate forage species will aid the year-round grazing and contribute to the overall resiliency and health of the system. Sheep will also be used to graze parkland and lawn areas in lieu of mowing, further reducing fuel usage (Boffa Miskell and Nelson Byrd Woltz Landscape Architects, 2014). The proposal to develop vegetable production beds, potager gardens, trial plots and arbors will also support the sustainable, local food production philosophy, and the farm-to-table vision. A new Farm Center will include Park maintenance infrastructure and offices, livestock sheds and holding pens, greenhouses and potting shed, production gardens, and has the potential to host a future farmers market. The six guiding principles used in developing the vision of the Master Plan broadly-Kaitiakitanga, Tikanga, Nga mahi ahuwhenua, Tiaki Onamata, Turnagawaewae, and Manaakitanga-can be seen to inform and direct design decisions with regards to the agricultural layer within the Master Plan, and specifically with regards to the continued integration and enhancement of grazing animals.

Kaitiakitanga-stewardship as guardian of the deep links between humans and the natural world, is depicted in relation to the agricultural design layer of the Park through the commitment to grazing animals playing a vital role in the continued function, maintenance, and holistic lifecycles of ecological systems within the Park. Tikanga-the principles and practices that embody the unique character of Cornwall Park see education and growing agricultural literacy within the urban population as being a key feature to the Master Plan and is illustrated through the proposed development of an agricultural hub within the Park, along with proposed community food growing and workshops, and a paddock to plate ethos for the Park's eateries. Expanding the educational program to include the interpretation of crops, historic gardens and contemporary sustainable gardening and farming techniques is also proposed by the Plan. The principle of Nga mahi ahuwhenua, guides the goal of exemplary agricultural practice within the Park, and is exemplified by the spatial and functional strategies illustrated within the 100 Year Master Plan to provide sustenance and nourishment for people and visitors. Depicted through the commitment to holistic health 
and well-being of the land, animals, water, and people, this principle is elucidated functionally through the proposal and development of diverse and multi-beneficial farming practices, such as agroforestry seen within the proposed development of the Olive grove where it is re-imagined as a place where orchard planting and grazing can co-exist. The principle of Tiaki Onamata aims to support, protect, save, and uplift the preservation and interpretation of the Park's cultural history, for which agriculture, both pre- and post-settlement is integral, and is illustrated through the protecting and prioritizing of historic agrarian features within the Park landscape, such as the precolonial kumara (sweet potato) gardens, the kumara pits on the Maunga, and the stone walls within the Park. The Master Plan also proposes the development of guidelines for farming in a historic landscapes with sensitive geologic and archaeological features. Turangawaewae, a place to stand and have a sense of belonging is represented within the agricultural layer of the Masterplan with the continued support and provision for visitors to have wide-reaching access to the paddocks and animals, where respect and care for the animals is encouraged through enhancing knowledge and accessibility. Finally, the principle of Manaakitanga, providing the enduring support, hospitality, and kindness for the parkland and animals that inhabit it, sees the Master Plan illustrate a design decision that will see pedestrians prioritized over cars within the Park. Cars will be relocated to the outer limits of the Park, thus further protection and enjoyment of the animals enhanced.

The Plan also proposed adjustment to pasture layout, accommodating changes to more holistic grazing regimes, as discussed above.

\section{CONCLUSION}

As global urbanization continues, the retention and creation of functioning productive grazing land both within and on the fringe of urban areas globally, is under increasing pressure from land development. There has been recent interest within the spatial design professions around the re-introduction and prioritization of plant-based agriculture within urban systems through community-based and civil initiatives such as community gardens, urban allotments, food forests, roof gardens, and urban orchards. The argument for the design of all cities into the future to integrate urban agriculture as essential infrastructure responds to concerns around low impact, transparent, and accessible food. Including animal agriculture for meat production in this future has been identified as a "gap" in urban design and planning research and practice. The potential of urban greenspaces to reintegrate grazing lands and accommodate urban animal agriculture could offer a supported spatial and operational structure to re-introduce animals for food production, back into the places where people live. The lack of research and implementation currently experienced for this type of urban agriculture, however, illustrates the often complex urban contexts within cities of the Global North. Inflexible planning rules, high land values, lack of suitable space, and public perception may all contribute to the difficulties that surround the re-integration of grazing lands for animal urban agriculture within cities of the Global North.

Today, many regional and city plans promote community gardens, food forests, urban composting, and city orchards as a way to increase social interaction and the health and wellbeing among their residents. The case study of Cornwall Park illustrates how the integration of livestock can provide essential services to both land management and maintenance, alongside visitor education, living heritage, and local food production. The 100 Year Master Plan (Boffa Miskell and Nelson Byrd Woltz Landscape Architects, 2014) provides a vision and commitment to the ongoing integration of grazing livestock within the central city park, harnessing benefits for humans, land, and the environment. Providing local meat and wool production within the limits of New Zealand's largest city, reduced fuel usage and greenhouse gas emissions, and the opportunity for agricultural education, experience and engagement for an urban populace, Cornwall Park and its animal agriculture provides an important visible story for urban residents of local food production that is normally invisible in urban life today.

The six principles, Kaitiakitanga; Tikanga; Nga mahi ahuwhenua; Tiaki Onamata; Turangawaewae; and Manaakitanga, integrated through the Master Planning process, provide underlying values that have guided the development of the Master Plan, and will be used to guide its future implementation. Each principle provides guidance in the decision making process around the inclusion and integration of animals within this urban park setting, and the prioritization of the agrarian landscapes into the future-illustrating its importance to both the functionality and spirit of this place.

This research set out to investigate how grazing lands for sheep and beef production can be designed within a public urban park alongside other park uses. The case study site of Cornwall Park, New Zealand, illustrates an example within the Global North context of how grazing lands are integrated, utilized, and indeed prioritized in vision-setting within an urban greenspace. Located within a medium - high density suburb, within the "urban zone" Cornwall Park provides an important exemplar of integrated animal urban agriculture for the Global North, contributing to the current gap in research and practice examples within this context and setting.

\section{DATA AVAILABILITY STATEMENT}

The raw data supporting the conclusions of this article will be made available by the authors, without undue reservation.

\section{AUTHOR CONTRIBUTIONS}

This research was carried out by SD including a review of the literature, study of the masterplan, and site visits to the case study site. 


\section{REFERENCES}

Attoe, W. (1978). Architecture and Critical Imagination. Chichester: Wiley

Boffa Miskell and Nelson Byrd Woltz Landscape Architects (2014). Cornwall Park Masterplan. Auckland: Cornwall Park Trust Board.

Bowring, J. (2020). Landscape Architecture Criticism. London: Routledge.

Brinkley, C., and Vitiello, D. (2014). From farm to nuisance: animal agriculture and the rise of planning regulation. J. Plann. Hist. 12, 113-135. doi: $10.1177 / 1538513213507542$

Duany, A., and DPZ. (2011). Garden Cities: Theory and Practice of Agrarian Urbanism. London: Duany Plater Zyberk \& Co.

Duany, A., and Talen, E. (2002). Transect planning. J. Am. Plann. Assoc. 63, 245-266. doi: 10.1080/01944360208976271

Feagan, R. (2007). The place of food: mapping out the "local' in local food systems. Progress Hum. Geogr. 31, 23-42. doi: 10.1177/0309132507073527

Francis, M. (2001). A case study method for landscape architecture. Landsc. J. 20, 15-29. doi: 10.3368/lj.20.1.15

Fredrickson, C. (2014). Measuring Auckland's Population Density. Auckland: Auckland Council. p. 33.

Google (2020). Google Earth [Data set]. Available online at: https://www.google. com/earth/

Journeaux, P., van Reenen, E., Manjala, T., Pike, S., Hanmore, I., and Millar, S. (2017). Analysis of Drivers and Barriers to Land Use Change: A Report Prepared for the Ministry of Primary Industries. Hamilton.

Kasper, C., Brandt, J., Lindschulte, K., and Giseke, U. (2017). The urban food system approach; thinking in spatialized systems. Agroecol. Sustain. Food Syst. 41, 1009-1025. doi: 10.1080/21683565.2017.1334737

Morgan, K. (2014). Nourishing the city: the rise of the urban food question in the Global North. Urban Stud. 52, 1379-1394. doi: 10.1177/0042098014534902

Morgan, K., and Sonnino, R. (2010). Yhe urban foodscape: world cities and the new food equation. Cambr. J. Regions Econ. Soc. 3, 209-224. doi: $10.1093 /$ cjres/rsq007

Mougeot, L. J. A. (2006). Growing Better Cities: Urban Agriculture for Sustainable Development. Ottawa, ON: International Development Research Centre.

Opitz, I., Berges, R., Piorr, A., and Krikser, T. (2016). Contributing to food security in urban areas: differences between urban agriculture and periurban agriculture in the Global North. Agric. Hum. Values 33, 341-358. doi: 10.1007/s10460-015-9610-2

Parham, S. (2015). Foof and Urbanism: The Convivial City and a Sustainable Future. London: Bloomsbury Academic.

Parham, S. (2020). Exploring food and urbanism. J. Urban. Int. Res. Placemaking Urban Sustain. 13, 1-12. doi: 10.1080/17549175.2020.1721152

Parham, S., and Abelman, J. (2018). "Food, landscape, and urban design," in Routledge Handbook of Landscape and Food, eds J. Zeunert and T. Waterman (London: Routledge), 409-432.
Pothukuchi, K., and Kaufman, J. (1999). Placing the food system on the urban agenda: the role of municipal institutions in food systems planning. Agric. Hum. Values 16, 213-224. doi: 10.1023/A:1007558805953

Pothukuchi, K., and Kaufman, J. (2000). The food system: a stranger to the planning field. J. Am. Plann. Assoc. 66, 113-124. doi: 10.1080/01944360008976093

Potteiger, M. (2013). Eating places: food systems, narratives, networks, and spaces. Landsc. J. 32, 261-275. doi: 10.3368/lj.32.2.261

Potteiger, M. (2015). "Eating ecologies: integrating productive ecologies and foraging at the landscape scale. Localizing urban food strategies," in Farming Cities and Performing Rurality 7th International Aesop Sustainable Food Planning Conference Proceedings (Torino).

Steel, C. (2008). Hungry City: How Food Shapes Our Lives. London: Chatto $\&$ Windus.

Steel, C. (2012). "Sitopia - harnessing the power of food," in Sustainable Food Planning: Evolving Theory and Practice, eds A. Viljoen and J. Wiskerke (Wageningen: Wageningen Academic Publishers), 37-46.

Steel, C. (2020). Sitopia: How Food Can Save the World. London: Chatto \& Windus.

The Cornwall Park Trust Board Inc (1994). Cornwall Park: The Story of a Man's Vision. Auckland: The Cornwall Park Trust Board Inc.

van Leeuwen, E., Nijkamp, P., and de Noronha Vaz, T. (2010). The multifunctional use of urban greenspace. Int. J. Agric. Sustain. 8, 20-25. doi: 10.3763/ijas.2009.0466

Viljoen, A. (ed.). (2005). CPULS Continuous Productive Urban Landscapes: Designing Urban Agriculture for Sustainable Cities. Oxford: Routledge.

Viljoen, A., and Bohn, K. (2005). Continuous productive urban landscapes: urban agriculture as an essential infrastructure. Urban Agric. Magazine 15, 34-36. Available online at: https://ruaf.org/

Viljoen, A., and Bohn, K. (ed.). (2014). Second Nature Urban Agriculture: Designing Productive Cities. (Oxfordshire: Routledge), 34-36.

Viljoen, A., Schlesinger, J., Bohn, K., and Drescher, A. (2015). "Agriculture in urban design and spatial planning," in Cities and Agriculture: Developing Resilient Urban Food Systems, eds P. Drechsel and H. de. Zeeuw (Abingdon: Routledge), 88-120.

Conflict of Interest: The author declares that the research was conducted in the absence of any commercial or financial relationships that could be construed as a potential conflict of interest.

Copyright (c) 2021 Davis. This is an open-access article distributed under the terms of the Creative Commons Attribution License (CC BY). The use, distribution or reproduction in other forums is permitted, provided the original author(s) and the copyright owner(s) are credited and that the original publication in this journal is cited, in accordance with accepted academic practice. No use, distribution or reproduction is permitted which does not comply with these terms. 